\title{
Konsepsi Pemerintahan Islam Menurut Muhammad Yusuf Musa
}

\author{
Matosim \\ \begin{tabular}{l|l} 
m_tosim98@gmail.com & $\begin{array}{l}\text { MA Al-Mu'awanah Palangan Karang } \\
\text { Binangun Lamongan, Indonesia }\end{array}$
\end{tabular}
}

\begin{abstract}
The Islamic world which was formerly strong and glorious has become one of the colonies of Western nations. This unquestionably impacts many countries that they are no longer want to use Islam as a form of their government, but prefer the concept of the nation (nationstate). Even among Muslims scholars, the concept of Islamic governance is still debatable and questionable. One of the Muslim scholars who concur with the idea of the Islamic government is Muhammad Yusuf Musa, a lecturer at AlAzhar Egypt, a graduate on Philosophy at the Faculty of Humanities at the University of Paris. This paper aims to find out Muhammad Yusuf Musa's thoughts about the Islamic government. The research found that according to Muhammad Yusuf Musa, the objectives of the Islamic government are (1) maintaining God's message on earth, and (2) improving human welfare by maintaining the unity and integrity of the people, helping each other and protecting the country from aggression and tyranny. Furthermore, the administration of the Islamic government demands two things, namely justice and shura. According to Musa, a leader must be chosen by the people, not by the appointment of the previous leader.
\end{abstract}

Key Word: Islamic Government, Muhammad Yusuf Musa

\begin{abstract}
Abstrak: Dunia Islam yang semula kuat dan jaya, satu demi satu menjadi negeri "jajahan" bangsa Barat. Ini tentunya berdampak, salah satunya banyak negara-negara yang tidak lagi mau menggunakan Islam sebagai dasar negara, dan lebih mendasarkan dasar negaranya kepada konsep bangsa (nation state). Bahkan dalam pemikir Islam sendiri konsep pemerintahan Islam masih diperdebatkan dan kontroversial. Salah satu tokoh Islam yang membicarakannya adalah Muhammad Yusuf Musa, salah satu pengajar di Al-Azhar Mesir, lulusan Filsafat pada Fakultas Sastra Universitas Paris. Tulisan ini bertujuan untuk mengetahui pemikiran Muhammad Yusuf Musa tentang pemerintahan Islam. Kesimpulan dari tulisan ini adalah bahwa menurut Musa tujuan pemerintahan Islam
\end{abstract}


adalah (1) menjaga amanat Allah dimuka bumi ini, dan (2) memperbaiki kondisi keduniaan, berupa menjaga persatuan dan kesatuan umat dan saling tolong-menolong, dan melindungi tanah air dari agresi dan kezaliman. Selanjutnya, dasar pemerintahan Islam, Musa mensyaratkan dua hal yaitu keadilan dan shürā. Di samping itu, menurut Musa seorang imam haruslah dipilih oleh umat, bukan dengan penunjukan imam sebelumnya.

Kata kunci: pemerintahan Islam, Muhammad Yusuf Musa

\section{Pendahuluan}

Dunia Islam yang semula kuat dan jaya di bidang politik, satu demi satu menjadi negeri "jajahan" bangsa Barat, seperti Palestina, Irak, dan Afganistan. Sebagian wilayah Islam adalah negeri-negeri jajahan yang dieksploitasi demi kepentingan penjajah. ${ }^{1}$ Melukiskan corak baru interaksi Barat-Timur ini. Imam Khomeni mengatakan bahwa bila dalam kontak lama Barat-Timur pada abad-abad sebelumnya Islam berada di pihak yang kuat, maka persentuhan dunia Islam dengan Barat di awal abad ini, seakan-akan memperlihatkan Islam sebagai sesuatu yang tidak berdaya dan permissive terhadap segala pengaruh dari Barat. ${ }^{2}$

Dunia Islam yang mengalami kontak dengan Barat modern memang bukan lagi dunia Islam pada masa jayanya dulu. Yang ada di masa modern adalah sebagian besar dunia Islam yang telah tercemar oleh khurafät dan adat-istiadat yang jauh dari Islam, yang dipertahankan dengan apologi dan reaksioner. Pengaruh-pengaruh dari Barat tampak kuat terutama bila memperhatikan orientasi pembaruan yang ditawarkan sementara pemikir Islam, semisal Muhammad Ali dari Mesir, Ahmad Khan dari Pakistan, dan Musthafa Kamal dari Turki. Mereka-merak ini memandang bahwa meniru Barat merupakan salah satu syarat bagi kemajuan

${ }^{1}$ Amerika dalam hal ini berdalih bahwa negara-negara yang mereka jajah tidak menerapkan dan menghormati nilai-nilai hak asasi manusia dan pemerintahan adalah rezim yang tirani dan otoriter. Untuk itu mereka melancarkan serangan hanya demi kepentingan mereka saja.

2 Imam Khomeini, Sistem Pemerintahan Islam, trans. oleh Muhammad Anis Mautachla (Jakarta: Pustaka Zahra, 2002), 12-27. 
Islam. ${ }^{3}$ Meskipun ada sebagian tokoh pemikir Islam yang mempertahankan keotentikan doktrin Islam, seperti Sayyid Qutb dan Muhammad Abduh yang dikenal sebagai pembaharu pemikiran Islam. ${ }^{4}$

Pada perkembangan selanjutnya, berkiblat ke Barat telah melahirkan ancaman baru berupa masuknya ideologi dan filsafat Barat materialistik, yang dalam banyak hal bertentangan dengan Islam, sehingga kaum Muslim semakin jauh dari ajaran yang asli. ${ }^{5}$ Aspek yang disebut terkemudian ini, juga merupakan bahaya lain yang harus dihadapi kaum Muslimin. ${ }^{6}$ Dengan demikian, pada saat bersamaan mereka menghadapi dua problem: kemunduran di bidang politik ekonomi dan ancaman ideologi Barat yang bertentangan dengan Islam. Di tengah kondisi yang seperti itu, paham Jabariah yang berkembang saat itu, telah membekukan kreativitas, ijtihad dan jihad. Itulah sebabnya terdapat variasi pandangan di kalangan pemikir Muslim tentang sebab keterbelakangan kaum Muslim dan upaya-upaya pemecahannya.

Tidak itu saja, banyak negara-negara yang tidak lagi mau menggunakan Islam sebagai dasar negara, ${ }^{7}$ Negara tersebut lebih mendasarkan dasar negaranya kepada konsep

3 Hampir semua pemikir-pemikir muslim kontemporer seperti, Abid AlJabiri, Muhammad Shahrur, Abdullah Ahmad Naim menyatakan bahwa umat Islam harus bisa menerima Barat, bahkan mereka seharusnya menjadikan Barat sebagai contoh. Lihat: Eka Dharmaputra, Pemikiran Islam Kontemporer (Bandung: Jendela, 2003), 12.

4 Harun Nasution, Pembaharuan dalam Islam: Sejarah Pemikiran dan Gerakan (Jakarta: Bulan Bintang, 1975), 68.

5 Padahal seorang muslim hidup di atas dunia ini adalah dengan cita-cita hendak menjadi seorang hamba Allah dengan arti yang sepenuhnya, mencari kejayaan di dunia dan kemenangan di akherat. Dunia dan akherat ini sekali-kali tidak mungkin dipisahkan oleh seorang muslim dari ideologinya. Lihat: Arif Wijaya, "Kedudukan Norma Hukum dan Agama dalam Suatu Tata Masyarakat Pancasila," Jurnal Al-Qānūn 11, no. 2 (Desember 2008): 327.

6 Eko Prasetyo, Membela Agama Tuhan: Potret Gcrakan Islam dalam Pusaran Konflik Global (Yogyakarta: Insist, 2001), 15.

7 Pada dasarnya teori hubungan Islam dan negara secara garis besar dibedakan menjadi trikotomi paradigma pemikiran. Yaitu (1) unified paradigm, (2) symbolic paradigm dan (3) secularistic paradigm. Lihat: Masruhan, "Pemikiran Kyai NU tentang Relasi Agama dan Negara," Jurnal Al-Qānūn 12, no. 1 (Juni 2009): 86. 
bangsa (nation state) yang nota benenya adalah produk dan budaya Barat. Bahkan dalam pemikir Islam sendiri konsep pemerintahan Islam masih diperdebatkan dan menjadi bahasan yang kontroversial. ${ }^{8}$

Lalu muncul di India Abū al-A'lā al-Maudūdy. ${ }^{9}$ Dia melihat Islam bukan hanya sebagai suatu ajaran normatif tetapi juga sebagai ideologi yang komprehensif. Di dalamnya terkandung sistem ekonomi Islam, sistem politik Islam, sistem hukum Islam, dan lain-lain. Pemikirannya ini didasari bahwa ajaran Islam mempunyai sifat yang sempurna bagi kehidupan negara dalam menjamin keragaman hidup antar berbagai golongan. ${ }^{10}$ Pemikiran al-Maudūdy ini, paling tidak menyadarkan umat Islam saat itu yang acap kali mengadopsi gagasan-gagasan dari Barat. ${ }^{11}$

Di Mesir lalu muncul Muhammad Yusuf Musa yang menyoal tentang pemerintahan Islam. Dia lahir di Mesir dan salah satu doktor pengajar di Al-Azhar Mesir. Pernah kuliah di Paris pada tahun 1945 di bidang Filsafat pada Fakultas Sastra Universitas Paris. Muhammad Yusuf Musa merupakan pemikir beraliran Sunni, yang berpandangan bahwa pemerintahan Islam dibangun atas dasar shürä dan keadilan. Sebab keduanya dilandaskan kepada Al-Qur'an sebagai sumber hukum Islam. ${ }^{12}$ Untuk itu, penulis mengasumsikan bahwa dengan meneliti pemikirannya maka penulis dapat mengetahui secara komprehensif dan holistik konsep pemerintahan dalam Islam.

${ }^{8}$ Ahmad A Sofyan dan M. Royhan Madjid, Gagasan Cak Nur tentang Negara dan Islam (Yogyakarta: Titian Ilahi Press, 2003), 11.

${ }_{9}$ Abu Dzarrin al-Hamidy, "Landscape Pemikiran Abu al-A'lā al-Mawdudi (1903-1979) Tentang Konsep Negara Islam," Jurnal al-Daulah 1, no. 2 (Oktober 2011): 208.

10 Saoki, "Islam dan Negara Menurut M. Natsir dan Abdurrahman Wahid," Al-Daulah: Jurnal Hukum dan Perundangan Islam 4, no. 2 (Oktober 2014): 349.

11 Meskipun mendapat kritik keras, namun al-Maudūdy dengan argumentasi-argumentasinya yang sistematis, ia mampu tetap bertahan dengan konsep dasar universalitas Islam (Islamic Universal World). Lihat: Idri, "Sistem Politik dan Pemerintahan Islam dalam Perspektif Abū al-A'lā al-Maudūdy," Jurnal Al-Qänūn 11, no. 1 (Juni 2008): 95.

12 Muhammad Yusuf Musa dan M. Thalib, Politik dan Negara dalam Islam (Surabaya: Al-Ikhlas, 1990), 182. 


\section{Biografi Muhammad Yusuf Musa}

Muhammad Yusuf Musa lahir di Kairo, Mesir 1910, Muhammad Yusuf Musa termasuk salah satu dosen Filsafat di Universitas Al-Azhar. Hal ini terungkap, ketika ia memberikan pengantar dalam buku "Islam: Suatu Kajian Komprehensif".13

Pendidikan Muhammad Yusuf Musa banyak ia tempuh di luar Negeri, yakni di Paris dan di Jerman. la pernah mengikuti pelatihan kepemudaan di Jerman pada tahun 1949. Selain itu, sejak tahun 1945 Muhammad Yusuf Musa mendapatkan beasiswa untuk belajar di Paris, Perancis. Di Paris, ia memperdalam filsafat pada Fakultas sastra Universitas Paris. ${ }^{14}$

Dari hal tersebut, dapat diketahui bahwa Muhammad Yusuf Musa termasuk pemikir Islam yang dididik oleh pendidikan luar negeri. Meskipun, pendidikan tersebut tetap tidak menpengaruhi pemikiran-pemikirannya tentang Islam. Atau dengan kata lain, kajian-kajian yang dilakukan oleh Muhammad Yusuf Musa masih tetap dalam kerangka pemikiran dasarnya, yakni sebagai pemikir sunni.

Menurut Luthfi Asyyaukanie, Muhammad Yusuf Musa adalah salah satu Doktor Al-Azhar yang mengkaji secara intens pemikir-pemikir Islam klasik. Muhammad Yusuf Musa bersama Amira Mathar dan Mahmud Qasim meneliti secara mendalam pemikiran dari Ibnu Rusyd. ${ }^{15}$

\section{Pemikiran dan Karya-karya}

Muhammad Yusuf Musa termasuk penulis yang produktif. Dalam beberapa dekade ia banyak menghasilkan tulisan-tulisan di segala bidang. Bahkan buku-bukunya telah diterjemahkan ke dalam bahasa Indonesia dan menjadi buku pegangang wajib bagi Mahasiswa di sejumlah IAIN di tanah air.

13 Muhammad Yusuf Musa, Islam: Suatu Kajian Komperhensif (Jakarta: Rajawali, 1988), iv.

14 Musa, xi.

15 A. Luthfi Assyaukanie, "Tipologi dan Wacana Pemikiran Arab Kontemporer," Jurnal Paramadina 1, no. 1 (1998): 62. 
Awalnya karya yang ditulis oleh Muhammad Yusuf Musa hanya seputar filsafat, Al-Qur'an serta filsafat Islam seperti al-Qur'an wa al-Falsafah (al-Qur'an dan filsafat), dan Bayn al-Din wa al-Falsafah (Antara Agama dan Filsafat) keduanya telah diterjemahkan ke dalam bahasa Indonesia. Akan tetapi Muhammad Yusuf Musa mulai menulis tentang hukum Islam semisal buku Nizām al-Hukm fi al-lslam (sistem pemerintahan dalam Islam). Deskripsi ini memperlihatkan betapa luasnya pemikiran beliau.

Banyak tokoh yang mengomentari terhadap karyakarya Muhammad Yusuf Musa. Tentunya ini merupakan suatu pengakuan yang menguatkan bahwa pemikiranpemikiran Muhammad Yusuf Musa mempunyai nilai keilmiahan yang tinggi, sehingga layak untuk dijadikan rujukan dalam mengkaji dan menelaah kajian-kajian kelslaman.

Salah satu contoh dari pemikiran Yusuf Musa adalah tentang sebuah pertanyaan, apakah Islam mewajibkan berdirinya Negara Islam. Yusuf Musa menjawab: "Memang bukanlah suatu keharusan untuk mengakui bahwa bangsa Arab Islam dahulu, sekalipun pada kurun awalnya telah ada sebuah negara yang melaksanakan dan memperhatikan serta mengurus kepentingan ummat sesuai dengan syari'at Allah dan Rasul-Nya. Dan memang, tidak kita dapati secara definitif di dalam Al-Qur'an dan sunnah yang shahih kaedahkaedah umum yang menjadi landasan tatanan pemerintahan dalam Islam. Akan tetapi dengan mengambil kesimpulan dari perilaku Rasulullah saw dan para sahabatnya di Madinah yang telah menjadikan negeri itu tanah air bagi mereka untuk selamanya, maka menjadi sempurnalah langkah bangsa Arab dan kaum muslimin dalam menegakkan sebuah negara yang memiliki segala unsur dan pilar-pilarnya, sebuah negara yang oleh Al-Qur'an dan sunnah Rasul diisyaratkan kewajiban untuk menegakkannya. Dan hal ini sesuai dengan definisi tata negara tentang negara itu sendiri. Sebuah negara yang memiliki pemimpin yang dipatuhi oleh seluruh kaum 
muslimin yang berbeda asal-usul, bangsa, dan warna kulitnya". 16

Islam mendidik manusia supaya bersih jiwanya, sehat pikirannya, cerdas akalnya, luas wawasan ilmunya dan kuat jasmaninya. Tetapi bagaimana hal itu bisa terjadi tanpa adanya sebuah negara dan pemerintahan yang eksistensinya tegak di atas dasar-dasar Islam? Jawaban bagi pertanyaan di atas adalah bahwa Islam yang agung telah mewajibkan kepada para pemeluknya untuk menjadi pemimpin di negaranya dan penguasa di bumi manapun mereka tinggal. Mereka harus mendakwahkan Islam, mengajak orang lain untuk masuk ke dalam Islam, hidup menurut ajaran alQur'an dan merasa tenang di bawah naungan petunjuk-Nya. Ummat muslim sesungguhnya memiliki potensi untuk memimpin bangsa dan ummat ini, asalkan mereka tetap melangkah dengan mantap menuju tujuan yang ditetapkan Allah dan Rasul-Nya. Dan bukannya menggapai tujuan yang ditetapkan manusia berdasarkan hawa nafsunya.

Bahwa ummat Islam harus memiliki negara, tempat atau wadah bagi dilaksanakannya syari'at yang mustahil dilakukan di dalam sebuah negara yang bukan negara Islam. Ini harus ditumbuhkan ke dalam hati setiap orang yang mengaku dirinya muslim. Dengan demikian negara hanyalah sebuah alat untuk mencapai tujuan. Yakni mewujudkan ajaran-ajaran Islam. ${ }^{17}$

\section{Pemikiran Muhammad Yusuf Musa tentang Pemerintahan Islam Tujuan Pemerintahan Islam}

Menurut Muhammad Yusuf Musa bahwa tujuan dari pemerintahan Islam adalah sebagai berikut: ${ }^{18}$

\footnotetext{
16 Assyaukanie, 63.

17 Saoki, "Islam dan Negara Menurut M. Natsir dan Abdurrahman Wahid," 350.

18 Dengan redaksi lain Jaenudin menyatakan, bahwa menurut Muhammad Yusuf Musa, tujuan utama negara dapat disebut tiga tujuan pokok: (1) memberikan penjelasan keagamaan yang benar dan menghilangkan keraguraguan terhadap hakikat Islam kepada seluruh manusia, (2) mengupayakan segala cara untuk menjaga persatuan umat dan saling tolong menolong sesama
} 
1. Melaksanakan aturan agama Allah

Pemikiran Muhammad Yusuf Musa tentang pemerintahan Islam tidak terlepas dari pembacaannya terhadap al-Qur'an dan Hadis ${ }^{19}$ serta beberapa ulama klasik seperti Ibnu Khaldun dan Al-Mawardi. Sebelum jauh membahas tujuan pemerintahan Islam, Muhammad Yusuf Musa mengingatkan kita untuk kembali mendifinisikan konsep imämah atau khilafah. Menurutnya dengan mendifinisikan imamah kita dapat mengetahui serta menjelaskan tujuan dari didirikannya pemerintahan Islam. la berpendapat bahwa imamah adalah kedudukan bagi pengganti Nabi saw. untuk memelihara agama dan mengatur dunia. Pendapat ini ia dasarkan pada pendapat Al-Mawardi. ${ }^{20}$

Pendapat lain yang ungkapkan dalam membahas imamah adalah pendapat Ibnu Khaldun yang mengartikan imamah sebagai berikut: "Khilafah adalah suatu pertanggungjawaban yang dipikulkan kepada seorang untuk mengusahakan kemaslahatan agama dan dunia yang bermuara pada kepentingan akhirat. Karena semua persoalan keduniaan, menurut pandangan agama, bermuara kepada kepentingan akhirat. Pada hakikatnya pemegang jabatan Khilafah sebagai pengganti dari Nabi saw. dalam menjaga agama dan mengatur dunia."

Dari dua pendapat ulama di ataslah Muhammad Yusuf Musa menyimpulkan tentang tujuan

mereka, dan (3) melindungi tanah air dari segala agresi dan seluruh warga negara dari kezaliman. Lihat: Jaenudin, "Hak dan Kewajiban Kepala Negara Menurut Hukum Islam” Jurnal “Adliya, no. 9 (Juli 2015): 119-20.

19 Menurut Mujtahid, bahwa Muhammad Yusuf Musa berkali-kali menyakatan konsep politiknya berupa "Islam adalah din dan daulah". Lihat: Mujtahid, "Menghidupkan Nilai Agama: Upaya Membangun Moralitas Kekuasaan dan Masyarakat Madani," Jurnal Ilmiah Bestari XIV, no. 32 (2001): 31.

20 Menurut al-Mawardy, negara adalah perwujudan dari kepemimpinan suatu kesatuan umat yang disebut dengan imāmah. Fungsinyameneruskan tugas kenabian,yakni memelihara agama dan mengatur dunia. Kewajiban mendirikan suatu "kepemimpinan" merupakan tanggung jawab bersama seluruh umat (farḍl kifayah). Lihat: Masruhan, "Pemikiran Kyai NU tentang Relasi Agama dan Negara," 89. 
pemerintahan Islam. Dengan mengutip dari kitab alMushāyirah ia menulis sebagai berikut: Bila dengan kedua definisi yang ringkas ini kita dapat memahami tujuan system pemerintahan, maka dalam buku "alMushāyirah" dan "sharah-nya" dikemukakan penjelasan luas tentang tujuan ini. Tujuan pertama adanya imamah ialah untuk melaksanakan ketentuan agama Allah sesuai dengan perintah Allah dan rasul-Nya dengan ikhlas serta patut dan untuk menghidupkan sunnah serta memerangi bid'ah, agar seluruh manusia dapat dengan baik melakukan ketaatan kepada Allah. ${ }^{21}$

Tujuan pertama dari pemerintahan Islam adalah menjaga amanat Allah di muka bumi ini. ${ }^{22}$ Sebab menurut Muhammad Yusuf Musa agama Islam tidak saja terbatas pada satu ummat saja, dibatasi oleh waktu. Hal ini berlainan dengan agama lain yang terbatas dengan waktu dan tempat, Yusuf Musa berkeyakinan akan Islam sebagai agama persatuan. Islam menyatukan seluruh aspek-kehidupan baik aspek, politik, sosial serta segisegi dunia lainnya.

Berkenaan dengan ini ia menjelaskan dengan panjang lebar dalam sebuah bukunya. Dia berkata: "Islam merupakan agama kesatuan, bukan agama tauhid semata. Kata tauhid telah mempunyai pengertian khusus yang tidak akan dilewatinya, yakni kepercayaan bahwa Tuhan itu Esa, Menciptakan langit dan bumi serta segala sesuatu yang diantara keduanya. Di samping itu, Islam tidak hanya menyerukan tauhid saja, melainkan ia berlandaskan pada kesatuan dalam segala hal; dalam segi ketuhanan, segi politik, segi sosial dan segi-segi dunia dan kehidupan yang lain."23

21 Musa dan Thalib, Politik dan Negara dalam Islam, 174.

22 Hal ini dikaranekan bahwa suatu pemerintahan yang menjalankan peraturan-peraturan dari Tuhan sebagaimana diterangkan oleh nabi-Nya wajib ditaati oleh rakyat, sebab pemerintah semacam itu pada prinsipnya bertindak sebagai wadah yang memberlakukan peraturan-peraturan Tuhan. Lihat: Idri, "Sistem Politik dan Pemerintahan Islam dalam Perspektif Abū al-A'lā alMaudūdy," 98-99.

23 Musa, Islam: Suatu Kajian Komperhensif, 15. 
Bila tujuan yang paling utama dari pemerintahan Islam adalah menjelaskan dan memelihara kemurnian agama, maka hal ini berarti imam harus berlaku keras terhadap setiap orang yang dengan terang-terangan ingin melepaskan diri dari agama atau tidak mau mengakui sesuatu kewajiban yang Allah tetapkan dalam al-Qur'an dan dijelaskan oleh Rasulullah di dalam sunnahnya. Oleh karena itu, pada awal masa pemerintahan khalifah Abu Bakar ra., dapat kita lihat beliau memerangi orang-orang yang murtad dari agamanya setelah wafatnya Rasulullah saw. ${ }^{24}$

Diceritakan oleh Muhammad Yusuf Musa bahwa waktu itu, yakni pada masa khaliffah Abu Bakar, banyak golongan bangsa Arab murtad dari Islam. Ada yang tidak mau menunaikan zakat, tetapi menerima kewajiban shalat. Khalifah pun bersikap keras tidak mau menerima kehendak mereka. Beliau bahkan berpendapat, bahwa memerangi mereka adalah suatu hak yang fundamental. Karena menerima sikap mereka yang tidak mau membayar zakat berarti melakukan suatu pemisahan yang tidak sah antara zakat dengan shalat. Di samping itu sikap semacam ini dapat dipandang suatu persetujuan terhadap kelemahan muslimin sepeninggal Rasulullah saw. ${ }^{25}$

Pendirian khalifah Abu Bakar di dalam hal ini mempunyai pengaruh yang besar terhadap Islam dan kaum muslim. Pasukannya yang dikirim untuk memerangi semua kelompok kaum murtad untuk memperoleh kemenangan dan Islam kembali jaya seperti keadaannya di setiap zaman. Dengan ini, kaum murtad dan orang-orang yang berjiwa munafik menyadari bahwa khalifah Rasulullah dan seluruh kaum

24 Pendapatnya ini dengan bahasa al-Maudūdy dikatakan bahwa: "Islam adalah suatu agama yang paripurna, lengkap dengan petunjuk untuk mengatur semua segi kehidupan manusia, termasuk kehidupan politik. Lihat: al-Hamidy, “Landscape Pemikiran Abu al-A'lā al-Mawdudi (1903-1979) Tentang Konsep Negara Islam," 216.

25 Musa dan Thalib, Politik dan Negara dalam Islam, 177. 
muslimin memikul kewajiban untuk membela agama terhadap mereka yang ingin merusaknya, dan juga berkewajiban untuk mengorbankan diri dan hartanya pada jalan Islam. ${ }^{26}$

Contoh lain adalah khaliffah Umar Ibn Khattab, ketika ia memegang jabatan khalifah mulai menjelaskan agama dan menempatkannya pada kedudukan yang tinggi dalam kebijakan-kebijakannya. Ia tidak pernah lupa menasehati para Gubernur dan para pegawainya mengenai kewajiban ini. Bahkan dalam salah satu khutbahnya beliau mengisyaratkan kewajiban tersebut. Ini seperti ucapan beliau: "Wahai manusia, demi Allah, aku tidak mengirimkan para pegawaiku kepada kalian untuk memukul diri kalian, dan tidak untuk merampas harta kalian. Akan tetapi aku kirim mereka kepada kalian, dan seterusnya." 27

Pendapat-pendapat Muhammad Yusuf Musa didasarkan kepada contoh-contoh yang telah terjadi pada al-Khulafä, ar-Rashidūn tersebut menjadi semacam contoh atau tauladan dari tujuan pemerintahan Islam. Selanjutnya Muhammad Yusuf Musa berkata sebagai berikut: "Peristiwa penting yang dihadapi oleh khalifah Abu Bakar pada awal pemerintahannya, seperti dapat kita saksikan, adalah problem kemurtadan. Akan tetapi selain problem ini juga ada peristiwa penting yang ditangani oleh beliau dengan sikap keras dan tekad baja. Langkah tersebut mempunyai pengaruh yang sangat menentukan terhadap menangnya kekuatan kaum muslimin dan upaya memelihara eksistensi mereka di hadapan para musuh yang senantiasa mengintai mereka dan setiap penjuru Yang kami maksud sebagai tindakan

26 Dalam bahasa al-Maudūdy, bahwa: kehidupan kenegaraan masa alKhulafā' al-Rashidūn adalah sebuah potret negara Islam yang betul-betul ideal. Hubungan antar para pelaksana pemerintahan dan rakyat yang begitu harmonis yang itu semua diliputi oleh semangat persaudaraan yang kuat. Lihat: al-Hamidy, “Landscape Pemikiran Abu al-A'lā al-Mawdudi (1903-1979) Tentang Konsep Negara Islam," 224.

27 Musa dan Thalib, Politik dan Negara dalam Islam, 178. 
ini ialah pengiriman pasukan Usamah Bin Zaid ra. yang tadinya telah disiapkan oleh Rasulullah saw. sebelum beliau wafat." 28

Penting dicatat bahwa Yusuf Musa mengidealkan tujuan dari pemerintahan Islam seperti para khalifah terdahulu. Oleh karenanya, umat Islam seharusnya melihat kepada mereka dalam menjalankan pemerintahan Islam. Mereka menjadikan keadilan sebagai prinsip pemerintahan mereka. Umat satu suaranya dan persatuan mereka kuat. Persatuan ini terjalin antara sesama muslim dan non-muslim dari berbagai agama, dimana mereka ini memperoleh hak dan kewajiban yang sama.

Untuk itulah pada masa-masa pertama kejayaan Islam banyak bangsa dan orang-orang dari agama lain yang jumlahnya hanya Allah swt. yang mengetahuinya masuk ke dalam Islam. Akan tetapi keadilan yang merata dan persamaan hak yang sebenarnya meliputi mereka semua, sehingga setiap orang merasa aman atas hak-haknya dan bersedia melaksanakan kewajibannya. Karena itu, orang yang tadinya bukan muslim lalu masuk ke dalam agama yang Allah ridlai untuk semua manusia.

2. Mengurus kehidupan dunia

Bagi Muhammad Yusuf Musa syariat Islam bukan saja mengurus keakhiratan belaka. Syariat Islam memiliki cakupan yang menyeluruh yang menyangkut hubungan manusia dengan Tuhan-Nya (habl minallah) atau hubungan manusia dengan manusia (habl minannas). Ia mengatakan: "Yang dimaksudkan dengan syariat Islam (legislasi) adalah semua peraturan agama yang ditetapkan oleh Allah untuk kaum muslimin, baik yang ditetapkan dengan al-Qur'an maupun dengan sunnah Rasul. Karena itu, syariat mencakup ajaran-ajaran pokok (ușul al-din) yakni yang ajaran yang berkaitan dengan Allah dan sifat-sifatnya, akhirat dan yang berkaitan

28 Musa dan Thalib, 178. 
dengan pembahasan-pembahasan ilmu tauhid yang lain. Di samping mencakup pula cara orang mendidik dirinya sendiri dan keluarganya, dasar-dasar hubungan kemasyarakatan dan cita-cita tertinggi yang harus diusahakan untuk dicapai atau didekati serta jalan untuk mencapai cita-cita atau tujuan hidup itu..."29

Dengan demikian tujuan selanjutnya dari pemerintahan Islam adalah memperbaiki kondisi keduniaan. Lebih kongkrit tujuan pemerintahan Islam dalam hal keduniaan adalah; pertama, mengupayakan segala cara untuk menjaga persatuan dan kesatuan umat dan saling tolong-menolong sesama mereka, memperbanyak sarana kehidupan yang baik bagi setiap warga umat sehingga seluruh umat dapat menjadi laksana bangunan yang kokoh.

Kedua, melindungi tanah air dari setiap agresi dan seluruh warga negara dari kezaliman, kedurhakaan dan tirani, memperlakukan mereka seluruhnya sama dengan memikul kewajiban dan memperoleh hak, tanpa adanya perbedaan antara amir dan rakyat, kuat dan lemah, kawan dan lawan.

Dari tujuan pemerintahan Islam ini sangat adil ketika Muhammad Yusuf Musa mengatakan bahwa antara tujuan akhirat dan tujuan dunia dalam pemerintahan Islam bersifat include. Artinya dalam doktrin ajaran Islam antara dunia dan ukhrawi saling berkelindan. Menurutnya dengan adanya dua tujuan ini, agama akan tetap berada dalam kehormatan dan kedudukan yang tinggi. Sedangkan umat hidup dalam persatuan, saling cinta dan saling menolong dalam kebaikan di waktu lapang maupun sempit. Setiap orang memperoleh rasa aman, baik pada diri, harta, kehormatan, dan hak-hak lainnya, sekalipun ia non-muslim. Sebaliknya kepada umat Islam diwajibkan menyokong setiap kegiatan yang diadakan oleh negara. ${ }^{30}$

${ }^{29}$ Musa dan Thalib, 131.

30 Muhammad Yusuf Musa, Al-Qur'an dan Filsafat (Jakarta: Bulan Bintang, 1988), 139. 


\section{Dasar-dasar Pemerintahan}

Menurut Muhammad Yusuf Musa, dasar-dasar dari pemerintahan Islam yaitu:

\section{Shüra}

Konsep shüra dalam doktrin politik Islam telah menjadi kesepakatan umum bagi para pemikir politik Islam. Konsep shüra adalah pilar dari tegaknya pemerintahan Islam yang didalamnya terdapat suatu mekanisme tata cara menyelesaikan segala persoalan yang terjadi.

Konsepnya terdapat dalam al-Qur'an pada QS. alShūrā (42): 38. ${ }^{31}$ Juga, pada QS. Ali 'Imrān (3): 159. ${ }^{32}$

Bagaimana dengan pemikiran Muhammad Yusuf Musa tentang shürā ini? Mengacu kepada ayat di atas Yusuf Musa beranggapan bahwa ayat tersebut mensiratkan tentang karakterislk dan keimanan seseorang. Menurutnya shürā merupakan ciri khas dari orang-orang mukmin.

Selanjutnya ia berkata: "Di dalam al-Quran ada sebuah surat yang menggunakan nama prinsip ini. Shüra dijadikan salah satu dari sifal khas orang-orang mukmin. Kemudian pada surat lain dengan terus terang diperintahkan melakukan musyawarah. Hal ini menunjukkan bahwa Islam mengutamakan musyawarah dan menjadikannya sebagai salah satu dasar pemerintahan dan cara mengatur kepentingankepentingan umat."33

31 Dalam QS. al-Shūrā (42): 38, yang artinya: "Dan urusan mereka dimusyawarahkan sesama mereka." Lihat: Departemen Agama RI. Al-Quran dan Terjemahan. (Bandung: Darus Sunnah, 2015), h. 2S9

32 Dalam QS. Ali 'Imrān (3): 159, yang artinya: "Karena rahmat dari Allah engkau berlaku lembut kepada mereka, sekiranya engkau kasar lagi keras hati, niscaya mereka menyingkir dari sekelilingmu. Karena itu maafkanlah mereka, mintakanlah ampun buat mereka dan bermusyawaralah dengan mereka di dalam urusan mereka. Jika engkau telah berketetapan hati, maka bertakwatal kepada Allah. Sungguh Allah mencintai orang-orang yang bertawakal".

33 Musa dan Thalib, Politik dan Negara dalam Islam, 182. 
Dengan mengutip pendapat Muhammad Abduh, Yusuf Musa mengatakan bahwa ayat tentang shüra tersebut adalah suatu kewajiban yang harus dilaksanakan dalam pemerintahan Islam. Ayat 159 dari surat ÂAi 'Imrān tersebut lebih tegas daripada ayat 38 dari surat Al-Shūrā (42), ayat pertama menjadi dasar kewajiban dari perintah shüra. Sedangkan ayat kedua sekedar menerangkan sifat golongan tertentu yang lebih banyak menunjukkan pujian terhadap sifat ini dan terpuji dalam pandangan Allah. ${ }^{34}$

Kemudian yang menjadi pertanyaan Yusuf Musa adalah apabila perintah tentang musyawarah diwajibkan kepada kepala negara dan ternyata tidak ada satupun yang bisa menjamin terlaksananya musyawarah tersebut apakah yang bersangkutan dapat dikenakan pelanggaran? Menyangkut hal ini Yusuf Musa mengembalikan kepada ayat yang ditafsiri sebagai kewajiban bermusyawarah. Dalam beberapa tafsir berbeda-beda mengenai kewajiban musyawarah sehingga dapat berakibat hukum pada pelanggarnya.

Sebagai bahasan dari bahasan shüra ini penulis kutip panjang lebar dari tulisan Muhammad Yusuf Musa: "Adapun QS. Āli 'Imrān (3): 104, sesungguhnya kewajiban adanya sekelompok anggota masyarakat yang bersatu lagi kuat untuk memikul tugas dakwah mengajak kepada kebaikan, menyuruh perbuatan ma'ruf dan mencegah kemungkaran. Tidak ada sesuatu perbuatan ma'ruf yang lebih tinggi dari keadilan dan tidak ada sesuatu kemungkaran yang lebih jahat daripada kedhaliman."

Namun, menurut pandangan kami, bahwa ayat yang mengandung kewajiban "amar ma'ruf" terhadap sekelompok orang diantara kita lebih menyangkut masalah cara yang efeklif membentengi masyarakat dari kedurhakaan, kedhaliman dan permusuhan serta menegakkan keadilan daripada menunjukkan adanya

34 Musa dan Thalib, 183. 
kewajiban memegang prinsip shürā. Apabila ayat ini dikatakan sebagai dalil yang paling kuat untuk menunjukkan adanya prinsip ini, Allah SWT. lebih tahu kebenaran dan apa yang dimaksudkannya dan apa yang dapat disimpulkan dari ayat tersebut." 35

Akhirnya penulis bisa mengambil kesimpulan bahwa; Pertama, Muhammad Yusuf Musa masihlah setengah hati dalam hal kewajiban shüra dalam sebuah negara. Satu sisi ia mengakui bahwa shüra merupakan salah satu dari dasar-dasar pemerintahan Islam, satu sisi yang lain ia hanya mengutip dari sejumlah pemikir bahwa shüra bukanlah kewajiban. Kedua, Muhammad Yusuf Musa tidak mempunyai konsep yang jelas tentang pola pelaksanaan shürā dalam pemerintahan Islam.

2. Keadilan

Konsep lain dari dasar-dasar pemerintahan Islam adalah keadilan. Keadilan merupakan dasar yang sangat fundamen dalam agama Islam. Islam diturunkan sematamata untuk menegakkan keadilan. Keadilan dalam agama Islam bersifat universal. la tidak pernah melihat suatu perbedaan yang terletak pada suku bangsa, agama ataupun etnik. Karakteristik dari keadilan Islam ini menunjukkan bahwa Islam tidak bermaksud sama sekali menafikan kemajemukan dan segala bentuk perbedaan.

Muhammad Yusuf Musa meletakkan keadilan sebagai asas pemerintahan. Apapun bentuk pemerintahan dan agamanya maka negara tetaplah menjadikan keadilan sebagai tujuan pokok. Akan tetapi keadilan dalam Islam bersifat mutlak lagi menyeluruh. Oleh sebab itu, Islam mewajibkan pengeterapannya terhadap kaum muslimin maupun non-muslim, teman ataupun lawan. Keadilan yang ditegakkan oleh system pemerintahan Islam dan dipandang sebagai salah satu dasarnya yang kuat adalah keadilan yang utama bagi semua orang, walaupun berbeda agama dan bangsa. Ia merupakan keadilan yang tidak terpengaruh oleh hubungan kerabat, kebesaran

35 Musa, Islam: Suatu Kajian Komperhensif, 19.

Al-Qānūn, Vol. 22, No. 1, Juni 2019 
dan kekuasaan. Sebaliknya juga tidak boleh terpengaruh oleh rasa benci atau permusuhan atau faktor apapun, selain yang tersebut diatas. ${ }^{36}$

Konsep Yusuf Musa ini didasarkan kepada al-Qur'an. Dalam ayat al-Qur'an Allah SWT. memerintahkan kepada ummatnya untuk berbuat adil, dan perbuatan sebaliknya dikecam. Sikap zalim terhadap sesama adalah bentuk prilaku yang diancam dengan balasan setimpal oleh Allah SWT., sebagaimana dalam QS. alAn'ām (6): $152 .{ }^{37}$

Secara khusus al-Qur'an memaktubkan bahwa seorang penguasa harus berbuat adil walaupun kepada dirinya sendiri, sebagaimana dalam QS. Al-Nisā' (4): $135 .{ }^{38}$

Keadilan dalam pemerintahan Islam tidak saja berlaku atau diperuntukkan kepada seorang muslim, akan tetapi juga kepada non-muslim. Sebab menurut Muhammad Yusuf Musa selama non-Muslim tinggal di negara Islam, maka mereka akan mendapatkan perlindungan dari Allah SWT. dan Rasul-Nya saw., sehingga merekapun punya hak dan kewajiban timbal balik terhadap negara Islam. ${ }^{39}$

\section{Kepemimpinan dalam Pemerintahan Islam}

Dalam wacana politik Islam klasik ada dua cara pemilihan pemimpin yang popular. Dua cara ini sudah

36 Musa dan Thalib, Politik dan Negara dalam Islam, 185.

37 Dalam QS. al-An'ām (6): 162, yang artinya: "Jika kamu berkata, maka berkatalah dengan adil walaupun kepada kerabat dekat. Dan janji Allah hendaklah kamu penuhi. Demikianlah dia mewasiatkan kamu untuk berbuat adil, mudah-mudahan kamu menjadi ingat."

38 Dalam QS. Al-Nisā' (4): 135 disebutkan, yang artinya: "Wahai orangorang yang beriman, jadilah kamu orang yang benar-benar penegak keadilan, menjadi saksi karena Allah biarpun terhadap dirimu sendiri atau ibu bapa dan kaum kerabatmu. Jika ia kaya ataupun miskin, maka Allah lebih tahu kemaslabatanya. Maka janganlah kamu mengikuti hawa nafsu karena ingin menyimpang dan kebenaran. Dao jika kamu memutarbalikkan (kata-kata) atau enggan menjadi saksi, maka sesungguhnya Allah adalah Maha Mengetahui segala apa yang kamu kerjaan."

39 Musa dan Thalib, Politik dan Negara dalam Islam, 186. 
disepakati oleh para pakar politik ketatanegaraan Islam periode awal seperti al-Mawardy, al-Baqillāny, Ibn Khaldūn dan sebagainya. Dua cara pemilihan tersebut adalah, pertama, penunjukan dari khalifah terdahulu kepada seseorang untuk menjadi penggantinya sesudahnya atau, kedua, dengan bai'at wakil-wakil umat jika para wakil rakyat mempunyai pendapat yang berbeda mengenai calon khalifah dan terdapat cukup dukungan suara terhadap calon tertentu. ${ }^{40}$

Kemudian bagaimana pendapat Muhammad Yusuf Musa tentang pengangkatan khaliffah? Berkenaan dengan hal ini ada beberapa pendapat beliau sebagai berikut:

Pertama, Muhammad Yusuf Musa memandang bahwa pemilihan khalifah dengan cara penunjukan khalifah terdahulu tidaklah dapat diterima. Sebab persoalan khalifah adalah masalah yang sangat serius dan penting. Menurutnya ada fakta-fakta yang membenarkan hal ini, yaitu:

1. Khalifah adalah wakil umat untuk memelihara dan membela agama dan untuk mengatur kepentingan negara.

2. Kekuasaannya bersumber kepada ummat yang memberinya kepercayaan dan mewakilkan kepadanya untuk melaksanakan apa yang menjadi tanggung jawabnya.

3. Transaksi perwakilan sama dengan transaksi-transaksi lain, yaitu berdasar kepada "asas penyerahan dari pihak pertama" dan "penerimaan dari pihak kedua".

4. Wakil berhenti karena diberhentikan oleh orang yang memberinya mandat. Begitu juga ia berhenti karena kematiannya. Diapun tidak berhak mengangkat orang lain untuk menggantikan dirinya tanpa persetujuan dan keridhaan ummat.

Berangkat dari empat dasar ini Muhammad Yusuf Musa berkata: "Bila fakta-fakta semacam ini kita tatap secara

40 Monoucher Paydar, Monoucher Paydar. Legilimasi Negara Islam: Problem Otoritas Syari'ah dan Politik Penguasa, Terj. M. Maufur El-Chory. Yogyakarta: Fajar Pustaka Baru, 2003, trans. oleh M. Maufur El-Chory (Yogyakarta: Fajar Pustaka Baru, 2003), 53. 
baik, kita akan memperoleh kejelasan bahwa pengangkatan khalifah secara syar'i maupun undang-undang tidak dapat dilakukan semata-mata berdasarkan penunjukan khalifah sebelumnya terhadap seseorang untuk menjadi penggantinya kemudian." 41

Dengan demikian jelaslah bahwa Muhammad Yusuf Musa menolak teori pemilihan khalifah dengan cara penunjukan khalifah sebelumnya.

Kedua, Muhammad Yusuf Musa walaupun menolak cara penunjukan akan tetapi ini tidak sepenuhnya. Menurutnya cara ini dapat dipergunakan dengan syarat khaliffah yang ditunjuk mendapat persetujuan serta di bai'at oleh ummat. Pendapat yang mendukung penunjukan semata tanpa dengan persetujuan ummat adalah pendapat yang kurang teliti. Walaupun pihak terakhir ini menerimanya. Akan tetapi harus ada persetujuan umat terhadap penunjukan tersebut dan pernyataan bai'at terhadap orang yang ditunjuk sebagai penggantinya.

Oleh sebab itu, adalah merupakan suatu gaya bahasa eufumisme atau mungkin kurang teliti apa yang dinyatakan oleh para pendukung pendapat yang telah kami sebutkan di atas bahwa pengangkatan kepala negara, khalifah atau imam tertinggi dapat dilakukan berdasarkan penunjukan khalifah sebelumnya sebagaimana dapat dilakukan dengan cara pembaiatan oleh ummat. ${ }^{42}$

Jika demikian maka penunjukan oleh khalifah sebelumnya sifatnya hanyalah pencalonan. Muhammad Yusuf Musa menegaskan bahwa hak pencalonan ini dimiliki oleh khalifah yang berkuasa sebagaimana juga dimiliki oleh setiap orang Islam.

Cara kedua tersebut di atas dalam pandangan Muhamad Yusuf Musa merupakan cara yang dipahami oleh para sahabat ataupun para ahli fikih. Dan apa yang pernah mereka praktekkan untuk pemilihan jabatan tertinggi negara yaitu jabatan khalifah atau imam tertinggi serta

41 Musa dan Thalib, Politik dan Negara dalam Islam, 126.

42 Musa dan Thalib, 126. 
sejarah telah menjadi saksi yang benar terhadap pendapat yang diuraikan Muhammad Yusuf Musa. Untuk menguatkan pendapatnya ini, Muhammad Yusuf Musa menerangkan bagaimana kedua cara ini dipraktekkan dalam pengangkatan khalifah Abu Bakar ra. dan khalifah Umar ra.

Misalnya dalam pengangkatan khalifah Abu Bakar sebagaimana yang telah kita ketahui adalah dari prakarsa Abu Ubaidah bin Jarrah ra. dan Umar Ibn Khattab ra. untuk membai'at beliau, sehingga perselisihan antara kaum Anshar dan Muhajirin tidak meruncing. Akan tetapi pengangkatan beliau pada dasarnya tidaklah berpijak pada tindakan semacam itu. Namun apa yang sebenarnya dilakukan oleh kedua orang tersebut di atas hanyalah bersifat pencalonan diri Abu Bakar ra. untuk jabatan khaliffah.

Dan yang sebenarnya menjadi dasar pengangkatan Abu Bakar ra. sebagai khalifah adalah adanya bai'at umat kepada beliau. Termasuk oleh orang-orang yang adil, berilmu, berpikiran dan anggota "ahl al-ḥall wa al-'aqd". Dengan adanya mereka membai'at beliau inilah kemudian umat mengikuti pendapat mereka. Begitu juga dalam pengangkatan khaliffah Umar ra. Tatkala khalifah Abu Bakar ra. telah merasakan begitu dekat dengan ajalnya, maka beliau menyerahkan kembali bai'at yang pernah diterimanya dari kaum muslimin dan meminta kepada sebagian umat untuk berkumpul dan memilih penggantinya guna mengurus kepentingan kaum muslimin. Akan tetapi mereka menyerahkan urusan ini kepada khalifah Abu Bakar ra. dan mengangkat beliau sebagai wakil untuk memilihkan imam buat mereka. Hal ini dikarenakan mereka ternyata tidak memperoleh kata sepakat untuk menunjuk salah seorang dari kalangan sendiri sebagai pengganti khalifah. ${ }^{43}$

Metode ini tidak berlaku hanya kepada khalifah Abu Bakar ra. dan khalifah Umar Ibn Khattab ra. Namun juga terjadi kepada khalifah Usman ra., khalifah Umar bin Abd. Aziz dan sebagainya. Terakhir Muhamad Yusuf Musa menegaskan bahwa dua cara pemilihan khalifah di atas

43 Musa dan Thalib, 127.

Al-Qānūn, Vol. 22, No. 1, Juni 2019 
adalah suatu metode yang mudah untuk direalisasikan. Sebab pencalonan khalifah terlebih dahulu dicalonkan oleh pakar baru kemudian disusul oleh bai'at mayoritas ummat.

\section{Hubungan Umat dengan Pemimpin}

Sebelum membahas tentang hubungan umat dengan pemimpin sebaiknya penulis terlebih dahulu mengetengahkan tentang satu bahasan yang sangat penting yakni sumber kekuasaan. Sumber kekuasaan amat penting untuk dibahas dikarenakan hal ini adalah dasar yang mendasari dari tata pemerintahan dan dari sinilah konsep pemerintahan Islam dibahas.

Muhammad Yusuf Musa berpendapat bahwa sumber kekuasaan ada pada ummat. Pendapat ini didasarkan kepada proposisi tentang kedudukan khalifah. Khalifah dalam pandangan Yusuf Musa hanya sebagai pemegang kekuasaan dalam negara. Akan tetapi di simpaing itu ia juga termasuk warga negara sama seperti yang lain. Tentang ini ia berkata: "Khalifah adalah pemegang kekuasaan dalam negara, dalam kedudukannya sebagai khalifah bukan sebagai pribadi, selama umat tetap menempatkan dirinya pada jabatan tertinggi ini".

Jabatan ini dimaksudkan agar ia dapat mengatur umat dengan hukum Allah dan syariat-Nya serta membimbingnya ke jalan kemaslahatan dan kebaikan, mengurus kepentingannya secara jujur dan adil dan memimpinnya ke arah kehidupan mulia dan terhormat. Sekalipun demikian, seorang khalifah tetap merupakan salah seorang warga itu sendiri, tetapi ia dipercaya untuk mengatur urusan agama dan dunia. Oleh karena itu, ia merupakan orang yang paling banyak tanggung jawab dan bebannya. Meskipun begitu, ia tidak dapat dengan semenamena memerintah orang lain dan beranggapan tak ada lagi kekuasaan yang melebihi dirinya serta merasa sebagai sumber kekuasaan dan kekuatan. ${ }^{44}$

44 Musa dan Thalib, 132. 
Pendapat Muhammad Yusuf Musa ini dihasilkan dari penafsirannya terhadap QS. al-Ghāshiyah (88): 21-2245 dan QS. Qāf (50): 45.46

Bersumber dan itulah Muhammad Yusuf Musa menyatakan bahwa sumber kekuasaan ada pada ummat. Khalifah adalah wakil umat untuk menangani kepentingan agama dan dunia selaras dengan syariat Allah dan RasuINya. Dengan demikian apabila khalifah berbuat salah, ummat mempunyai hak untuk menasehati, meluruskan, dan mengoreksi bahkan mempunyai hak untuk memecat bila terdapat alasan sah untuk bertindak demikian. Maka sangat rasional kalau sumber kekuasaan tetap ada pada pemberi mandat, bukan pada pemegang mandat.

Tesis ini dijelaskan kembali dalam al-Qur'an yang memuat perintah kepada kaum muslimin mengenai masalah-masalah umum. Ini dimaksudkan untuk menyatakan bahwa kaum muslimin adalah sumber kekuasaan bagi para eksekutif dan juga sebagai pengawas terhadap eksekutif. ${ }^{47}$

Ayat-ayat tersebut mendeskripsikan bahwa umatlah yang memikul tanggung jawab menegakkan agama, syariat Ilahi dan memelihara kemaslahatan umum. Hal ini berarti pula bahwa umat menjadi sumber kekuasaan tertinggi negara dan mengawasinya serta mengawasi para pejabat negara.

45 Dalam QS. al-Ghāshiyah (88): 21-22 disebutkan, yang artinya: "Berilah peringatan! Engkau sebenarnya hanya seorang pemberi peringatan. Engkau sama sekali bukan penguasa mereka".

46 Salam QS. Qāf (50): 45 disebutkan, yang artinya: "Kami lebih mengetahui perkataan mereka dan engkau sama sekali bukanlah pemaksa terhadap mereka. Karena itu berilah peringatan dengan al-Qur'an terhadap orang yang takut kepada ancaman".

47 Hal tersebut berdasarkan QS. Al- Nisā' (4): 135, yang artinya: "Wahai orang-orang yang beriman, jadilah kamu orang yang benar-benar penegak keadilan, menjadi saksi karena Allah biarpun terhadap dirimu sendiri atau ibu bapa dan kaum kerabatmu. Jika ia kaya ataupun miskin, maka Allah lebih tahu kemaslahatannya. Maka kamu mengikuti hawa nafsu karena ingin menyimpang dan kebebasan. Dan jika kamu memutar balikkan (kata-kata) atau enggan menjadi saksi, maka sesungguhnya Allah adalah Maha Mengetahui segala apa yang kamu kerjaan." 
Penulis telah membahas tentang sumber kekuasaan, pembahasan selanjutnya adalah tentang hubungan umat dengan penguasa. Di atas telah disebutkan bahwa khalifah hanyalah seseorang yang dipilih oleh ummat untuk menjadi mandataris dan menangani kepentingan serta kebutuhan umat. Untuk itu umat berkewajiban untuk menyampaikan nasihat bila dipandang perlu. Bahkan ia wajib memberikan kontrol maupun bimbingan. Selain itu, ia berhak memecatnya jika terdapat alasan-alasan yang sah seperti halnya berlaku dalam hubungan seseorang terhadap orang lain yang diberinya mandat. ${ }^{48}$

Muhammad Yusuf Musa mengatakan bahwa dalam agama Islam tidak mengenal adanya kedudukan istimewa seorang khalifah terhadap umatnya. Dimana dengan kedudukannya ia tidak lagi memerlukan nasehat, bimbingan dan bebas dari kewajiban-kewajiban tertentu yang berlaku kepada umatnya. Khalifah juga tidak memiliki sifat kesucian sebagaimana Tuhan atau "Kudus" sekalipun. la tidak mempunyai wewenang tunggal dalam menafsirkan dan menjelaskan ketentuan-ketentuan agama dan tidak pula mempunyai kekuasaan terhadap diri orang lain. Ia hanyalah seseorang yang karena kapabilitas dan integritasnya memperoleh kepercayaan umat untuk menangani dan mengurus kepentingan mereka berdasarkan perintah dan syarial Allah. ${ }^{49}$

Menurut Muhammad Yusuf Musa konsep khalifah berbeda dengan konsep Theokratis dalam termenologi barat. Theokratis dianggap sebagai penguasa titisan Tuhan yang mendapatkan hukum langsung dari Tuhan, berhak membuat

48 Dalam konteks negara modern dikatakan bahwa negara memang memerlukan dasar normatif, suatu sistem nilai dan pandangan tentang manusia yang mendasari kebijaksanaan-kebijaksanaannya. Akan tetapi, sistem nilai itu tidak boleh diciptakan oleh mereka yang kebetulan tengah berkuasa, tetapi harus diambil dari masyarakat sendiri, harus merupakan perwujudan kepribadian moral bangsa dan masyarakat sendiri. Jadi, sistem nilai yang mendasari kehidupan bernegara harus berorientasi kepada nilai-nilai yang hidup di dalam masyarakat dan bukan sebaliknya. Lihat: Wijaya, "Kedudukan Norma Hukum dan Agama dalam Suatu Tata Masyarakat Pancasila," 336.

49 Musa dan Thalib, Politik dan Negara dalam Islam, 146. 
hukum sendiri dan wajib ditaati oleh rakyatnya secara mutlak, tanpa melalui bai'at dan tidak dipersyaratkan berlaku adil serta membela kepentingan rakyat. ${ }^{50}$

\section{Penutup}

Dari berbagai pemaparan di atas, maka bisa disimpulkan hal-hal bahwa pemikiran Muhammad Yusuf Musa tentang pemerintahan Islam adalah sebagai berikut:

1. Muhammad Yusuf Musa menyatakan bahwasanya tujuan pemerintahan Islam adalah menjaga amanat Allah di muka bumi ini. Sebab menurut Muhammad Yusuf Musa agama Islam tidak terbatas pada satu ummat dan dibatasi oleh waktu. Hal ini berlainan dengan agama lain yang terbatas dengan waktu dan tempat. Selain itu pula tujuan dari pemerintahan Islam ialah memperbaiki kondisi keduniaan. Lebih kongkrit tujuan pemeritahan Islam dalam hal keduniaan adalah: (1) Mengupayakan segala cara untuk menjaga persatuan dan kesatuan umat dan saling tolong-menolong sesama mereka, memperbanyak sarana kehidupan yang baik bagi setiap warga umat sehingga seluruh umat dapat menjadi laksana bangunan yang kokoh; dan (2) Melindungi tanah air dari setiap agresi dan seluruh warga negara dari kezaliman, kedurhakaan dan tirani, memperlakukan mereka seluruhnya sama dengan memikul kewajiban dan memperoleh hak, tanpa adanya perbedaan antara amir dan rakyat, kuat dan lemah, kawan dan lawan.

2. Berkenaan dengan dasar pemerintahan Islam, Muhammad Yusuf Musa mensyaratkan dua hal yaitu keadilan dan shürá.

3. Seorang imam dalam pandangan Muhammad Yusuf Musa dipilih tidak dengan penunjukan imam sebelumnya melainkan dipilih oleh umat.

\section{Daftar Pustaka}

50 Musa dan Thalib, 141.

Al-Qānūn, Vol. 22, No. 1, Juni 2019 
Assyaukanie, A. Luthfi. "Tipologi dan Wacana Pemikiran Arab Kontemporer." Jurnal Paramadina 1, no. 1 (1998).

Dharmaputra, Eka. Pemikiran Islam Kontemporer. Bandung: Jendela, 2003.

Hamidy, Abu Dzarrin al-. "Landscape Pemikiran Abu al-A'lā alMawdudi (1903-1979) Tentang Konsep Negara Islam." Jurnal al-Daulah 1, no. 2 (Oktober 2011).

Idri. "Sistem Politik dan Pemerintahan Islam dalam Perspektif Abū al-A'lā al-Maudūdy." Jurnal Al-Qānūn 11, no. 1 (Juni 2008).

Jaenudin. "Hak dan Kewajiban Kepala Negara Menurut Hukum Islam” Jurnal “Adliya, no. 9 (Juli 2015): 2.

Khomeini, Imam. Sistem Pemerintahan Islam. Diterjemahkan oleh Muhammad Anis Mautachla. Jakarta: Pustaka Zahra, 2002.

Masruhan. "Pemikiran Kyai NU tentang Relasi Agama dan Negara." Jurnal Al-Qänūn 12, no. 1 (Juni 2009).

Mujtahid. "Menghidupkan Nilai Agama: Upaya Membangun Moralitas Kekuasaan dan Masyarakat Madani." Jurnal Ilmiah Bestari XIV, no. 32 (2001).

Musa, Muhammad Yusuf. Al-Qur'an dan Filsafat. Jakarta: Bulan Bintang, 1988.

-_- Islam: Suatu Kajian Komperhensif. Jakarta: Rajawali, 1988.

Musa, Muhammad Yusuf, dan M. Thalib. Politik dan Negara dalam Islam. Surabaya: Al-Ikhlas, 1990.

Nasution, Harun. Pembaharuan dalam Islam: Sejarah Pemikiran dan Gerakan. Jakarta: Bulan Bintang, 1975.

Paydar, Monoucher. Monoucher Paydar. Legilimasi Negara Islam: Problem Otoritas Syari'ah dan Politik Penguasa, Terj. M. Maufur El-Chory. Yogyakarta: Fajar Pustaka Baru, 2003. Diterjemahkan oleh M. Maufur El-Chory. Yogyakarta: Fajar Pustaka Baru, 2003.

Prasetyo, Eko. Membela Agama Tuhan: Potret Gcrakan Islam dalam Pusaran Konflik Global. Yogyakarta: Insist, 2001.

Saoki. "Islam dan Negara Menurut M. Natsir dan Abdurrahman Wahid." Al-Daulah: Jurnal Hukum dan Perundangan Islam 4, no. 2 (Oktober 2014).

Sofyan, Ahmad A, dan M. Royhan Madjid. Gagasan Cak Nur tentang Negara dan Islam. Yogyakarta: Titian Ilahi Press, 2003.

Wijaya, Arif. "Kedudukan Norma Hukum dan Agama dalam Suatu Tata Masyarakat Pancasila." Jurnal Al-Qānūn 11, no. 2 (Desember 2008). 